\title{
Relationship Marketing: A Strategy for Marketing Programs to Diverse Audiences ${ }^{1}$
}

\section{Lisa A. Guion and Heather Kent ${ }^{2}$}

This paper is the eighth in a series of articles on planning programs to effectively outreach to diverse audiences. This series will include specialized papers on enhancing cultural competence, recruiting diverse volunteers, planning culturally appropriate marketing strategies, and other topics that are integral to the design and implementation of culturally relevant Extension education programs.

\section{Overview}

Marketing, in general, means publicizing your name, program, and service to your target audience. Relationship marketing is the process of attracting, maintaining, and enhancing relationships with key individuals over time. Current research in the field of marketing indicates that forming constructive relationships with select target customers is more important for long-term success than acquiring widespread public awareness within a community.

The success of Extension programs is due to the loyalty of committed participants, volunteers, and lay leaders, as well as support from local decision-makers and elected officials. Since its inception, Extension has been fostering those relationships with core constituencies. Unfortunately, in some cases, these core constituency groups did not include people of color or limited-resource audiences. If Extension is to truly build relationships with these diverse audiences, time and attention must be invested in establishing mutually beneficial relationships. A basic understanding of diversity is crucial when developing strategies for relationship marketing.

Relationship marketing involves the use of one-on-one communication to earn the loyalty of your target audience. While personal marketing (discussed in EDIS fact sheet FY757, "Personal Marketing: A Strategy for Marketing Programs to Diverse Audiences") helps you to get your message across in a way that will be better received, relationship marketing helps you to strengthen your relationship with your target audience (DeYoung, B. \& Boldt, 1998). Relationship marketing is high-touch, person-to-person communication. And it is the most powerful and time-consuming marketing technique.

1. This document is FCS9224, one of a series of the Family Youth and Community Sciences Department, Florida Cooperative Extension Service, Institute of Food and Agricultural Sciences, University of Florida. Original publication date Septmeber 2005. Visit the EDIS Web Site at http://edis.ifas.ufl.edu.

2. Lisa A. Guion, Ed.D., associate professor, Department of Family, Youth and Community Sciences, Florida Cooperative Extension Service, Institute of Food and Agricultural Sciences, University of Florida, Gainesville, FL 32611; and Heather Kent, M.S., extension agent II, Cooperative Extension Serivce, Institute of Food and Agricultural Sciences, Marianna, FL 32448.

The Institute of Food and Agricultural Sciences (IFAS) is an Equal Opportunity Institution authorized to provide research, educational information and other services only to individuals and institutions that function with non-discrimination with respect to race, creed, color, religion, age, disability, sex, sexual orientation, marital status, national origin, political opinions or affiliations. U.S. Department of Agriculture, Cooperative Extension Service, University of Florida, IFAS, Florida A. \& M. University Cooperative Extension Program, and Boards of County Commissioners Cooperating. Larry Arrington, Dean 
Relationship marketing suggests that once your program takes off, your intentions are to be there for the long haul (not just while you have a targeted grant, as may have been the case with many other programs in the community). Diverse communities are accustomed to the short attention span of programs that come in and make a lot of promises, then leave after one or two years when their grants have run out. Consequently, many lose confidence in organizations/agencies. We must show our audiences how Extension is different, and that we are committed for the long-term.

\section{Customer Retention Marketing}

Customer Retention Marketing (CRM) is the foundation of relationship marketing. In Extension, the goal of CRM is to convert the target audience into loyalists and loyalists into enthusiasts, advocates, and donors. Here is a useful strategy:

\section{Step 1}

You will first need to identify the diverse audience with whom you wish to build a relationship. Then you will need to find out the answers to key questions:

- What does this audience know about Extension and/or your program?

- How does this audience feel about Extension and/or your program (positive or negative)?

- What needs does this audience have that your program can meet?

\section{Step 2}

If they know about Extension and your program, and have favorable feelings towards it, then you will have to keep maintaining a good relationship with your audience by keeping in touch with them through impersonal marketing techniques like mailings, flyers, etc.

If they know about Extension and/or your program, but have negative or indifferent feelings towards it, then you will need to change this negative image before you can build trust. This can begin to happen when you apply The six Ps technique of personal marketing, with special emphasis on promotion and price. (The six $P^{\prime}$ s are covered in EDIS fact sheet FY757, "Personal Marketing: A Strategy for Marketing Programs to Diverse Audience").

If the audience does not know much about Extension and/or your program, then you must inform them. You can do this by applying The six P's technique of personal marketing.

\section{Step 3}

Identify the assets that individuals or institutions in the diverse audience possess. Use the assets of these individuals and institutions to carry out your programs. Volunteers can have short or long-term assignments. These experiences help build program ownership and foster even more participation. (EDIS fact sheet FY760, "Maximizing the Assets of A Diverse Community" will deal specifically with how to identify the individual and/or institutional assets of diverse audiences.)

\section{Step 4}

Actively solicit the increased participation and involvement of community members, which will foster greater loyalty to the program.

\section{Step 5}

Encourage greater support from community members. Loyal individuals are more likely to advocate for the program and/or donate resources to the program.

Each of these steps takes time and attention. Relationship marketing must be nurtured.

\section{Conclusion}

Relationship marketing is one of the most time-consuming, but most effective strategies for marketing Extension programs. Relationship marketing is a process, not a one-time event; clientele must understand that you are committed long-term and that they can depend on you to provide education. 
To be effective, you must establish a relationship with the audience you are targeting by making a connection with them over time. In order to build a relationship, as with any other relationship in life, Extension needs to be constantly in touch with its audiences. By making a connection with diverse audiences, Extension can build strong community networks that promote the programs we market beyond the limited scope of small workshops and community meetings.

\section{Reference}

DeYoung, B., \& Boldt, W. (1998). Relationship marketing: Putting relationships to work. Ithaca, NY: Cornell Cooperative Extension Marketing Manual.

Guion, L. A., Goddard, H. W., Broadwater, G., Chattaraj, S., \& Sullivan-Lytle, S. (2003). Strengthening programs to reach diverse audiences. Gainesville, FL: Florida Cooperative Extension, University of Florida.

\section{EDIS Fact Sheets in the Planning Culturally Relevant Programs Series}

\section{Guion, L.A. (2005). An Overview of} Diversity [Online]. EDIS. Florida Cooperative Extension Service, University of Florida. http://edis.ifas.ufl.edu/FY752

2. Guion, L.A. (2005). Reaching Diverse Audiences [Online]. EDIS. Florida Cooperative Extension Service, University of Florida. http://edis.ifas.ufl.edu/FY753

3. Guion, L.A., \& Brown, K. (2005). Culturally Competent Extension Educators [Online]. EDIS. Florida Cooperative Extension Service, University of Florida. http://edis.ifas.ufl.edu/FY754

4. Guion, L.A., \& Harper Golden, J. (2005). Culturally Diverse Advisory Boards and Volunteers [Online]. EDIS.Florida Cooperative Extension Service, University of Florida. http://edis.ifas.ufl.edu/FY755

5. Guion, L. A., \& Walker, N. (2005). Planning Programs to Break Down Cultural Barriers [Online].
EDIS. Florida Cooperative Extension Service, University of Florida. http://edis.ifas.ufl.edu/FY756

6. Guion, L. A. (2005). Personal Marketing: A Strategy for Marketing Programs to Diverse Audiences [Online]. EDIS. Florida Cooperative Extension Service, University of Florida. http://edis.ifas.ufl.edu/FY757

7. Guion, L. A.,\& Kent, H. (2005). Ethnic Marketing: A Strategy for Marketing Programs to Diverse Audiences [Online]. EDIS. Florida Cooperative Extension Service, University of Florida. http://edis.ifas.ufl.edu/FY758

8. Guion, L. A., \& Kent, H. (2005). Relationship Marketing: A Strategy for Marketing Programs to Diverse Audiences [Online]. EDIS. Florida Cooperative Extension Service, University of Florida. http://edis.ifas.ufl.edu/FY759

9. Guion, L.A., \& Harper Golden, J. (2005). Maximizing The Assets Of A Diverse Community [Online]. EDIS. Florida Cooperative Extension Service, University of Florida. http://edis.ifas.ufl.edu/FY760

10. Guion, L. A. (2005). Enhancing Instruction To Connect With Diverse Audiences [Online]. EDIS. Florida Cooperative Extension Service, University of Florida. http://edis.ifas.ufl.edu/FY761 